УДК $575.24+633.11$

\title{
ГЕНОЗАЩИТНОЕ СВОЙСТВО СЕСКВИТЕРПЕНОВОГО ЛАКТОНА ТАУРЕМИЗИНА
}

\author{
() Н.Ч. Бахиыева ${ }^{I}$, С.В. Серкеров ${ }^{2 *}$ \\ ${ }^{1}$ Институт генетических ресурсов национальной Академии наук \\ Азербайджана, пр. Азадлые, 155, Баку, AZ1106 (Азербайджан) \\ ${ }^{2}$ Институт ботаники национальной Академии наук Азербайджана, \\ Бадамдарское шоссе, 40, Баку, AZ1073 (Азербайджан), e-mail: s.serkerov@mail.ru
}

В данной статье описано получение сесквитерпенового лактона тауремизина из полыни таврической с целью выявления его возможного антимутагенного эффекта. Показано влияние сесквитерпенового лактона тауремизина на частоту индуцированных $\gamma$-облучением аберраций хромосом на семенах мягкой пшеницы. Проведена оценка антимутагенной активности тауремизина в отношении мутационного процесса, индуцированного $\gamma$-облучением у семян мягкой пшеницы (Triticum aestivum L.var.graecum) и установлена наиболее эффективная его концентрация.

Ключевые слова: Artemisia taurica, сесквитерпеновые лактоны, антимутагенная активность, аберрации хромосом, митотическая активность, всхожесть семян.

\section{Введение}

Ген, будучи единицей наследственности, также является неотъемлемой частью генома. Геном, в свою очередь, постоянно находится под действием различных факторов среды обитания. Наличие в среде обитания новых техногенных и биогенных факторов не исключает их прямого или косвенного воздействия на живые организмы. Многие из этих факторов, попавших в среду в результате негативных явлений, связанных с научно-техническим прогрессом, обладают генотоксичностью, что имеет текущие и отдаленные последствия.

Предотвращение генетических последствий загрязнения окружающей среды является актуальной задачей, реализация которой может осуществляться различными взаимодополняющими путями [1] и решаться в разных направлениях. В связи с этим становится очевидной важность научных исследований и практических разработок, которые ведутся в области профилактики последствий загрязнения окружающей среды на основе компенсационного подхода, предполагающего повышение устойчивости генетического аппарата и его защиту от мутагенных факторов путем стабилизации естественного и снижения индуцированного мутационного процесса [2]. Защита живых организмов от поражающего действия ионизирующих излучений - одна из актуальных проблем в современной биологии. Она тесно связана с общебиологическими вопросами устойчивости живых систем к неблагоприятным факторам. Это обусловлено тем, что в процессе эволюции организмы, в том числе и растительные, выработали ряд защитноприспособительных систем жизнеобеспечения в экстремальных условиях. И радиоустойчивость, несомненно, является результатом функционирования этих систем [3].

В настоящее время стало общепризнанным, что лучевое поражение на тех или иных этапах его раз-

Бахшиева Нигяр Чингиз кызы - младший научный сотрудник, e-mail: s.serkerov@mail.ru

Серкеров Сираджеддин Вели оглу - заслуженный

деятель науки Азербайджана, доктор химических наук, профессор, главный научный сотрудник,

e-mail: s.serkerov@mail.ru вития и на разных уровнях структурно-функциональной организации живой системы поддается модификации. Поэтому среди различных аспектов решения проблемы защиты растений от лучевого поражения важное место занимает поиск радиопротекторов

\footnotetext{
* Автор, с которым следует вести переписку.
} 
и оценка их влияния на процесс возникновения мутаций [4]. В связи с этим исследования, направленные на выявление биологически активных веществ из растительных источников, обладающих генозащитными свойствами, представляют значительный интерес. С одной стороны, они позволяют оценить роль различных метаболитов в регуляции генетической устойчивости растений, с другой - выявить перспективные виды растений, являющихся ценными источниками получения фармакологических средств и пищевых добавок с генозащитными, антиоксидантными и геропротекторными свойствами [5].

Одно из актуальных направлений в проблеме защиты генетического аппарата от повреждающего воздействия факторов окружающей среды - применение биологически активных соединений [6-8]. Особый интерес представляют сесквитерпеновые лактоны, получаемые из видов рода (ArtemisiaL.), которые применяются в народной и официнальной медицине. Интерес к сесквитерпеновым лактонам со стороны химиков и фармакологов за последние годы значительно возрос. Это вызвано тем, что обнаружены сесквитерпеновые лактоны, обладающие широким спектром биологической активности. Известны их цитотоксическое, антилейкемическое, антибактериальное, противоожоговое, кардиотоническое, антипротозойное и другие действия. Они также обладают ростостимулирующей, фунгицидной, инсектицидной, реппелентной, антимутагенной активностью [9].

Цель нашей работы - изучение влияния сесквитерпенового лактона тауремизина, полученного из полыни таврической (Artemisia taurica Willd.), на семена мягкой пшеницы (Triticum aestivum L. var. graecum), $\gamma$-облученные в дозе 10 грей, для выявления его возможного антимутагенного эффекта.

Имеются сведения о том, что тауремизин оказывает стимулирующее действие на центральную нервную систему и на диурез, но главным объектом его действия является сердце [10]. Он обладает положительным ино- и тонотропным и отрицательным хронотропным свойствами [11].

\section{Экспериментальная часть}

Выделение и идентификация тауремизина. Сумму экстрактивных веществ (10,0 г), полученную путем экстракции ацетоном надземной части (0,5 кг) полыни таврической (Artemisia taurica Willd.), coбранной в период цветения в окрестностях 25-го участка - пос. Самур Кусарского района Азербайджанской Республики в июне 2011 г. (гербарные материалы определены Н.С. Филатовой (БИН РАН, СанктПетербург) и А.Н. Алескеровой (Институт ботаники) и хранятся в Институте ботаники НАН Азербайджана под номером №16700), хроматографировали на колонке $(h=55, d=2,5)$ заполненной нейтральной окисью алюминия (III-IV ст. акт. по Брокману), элюировали гексаном, бензолом, хлороформом и смесями различных их соотношений. Из 22-26 фракций, элюируемых смесью бензола с хлороформом в соотношении $1: 2$, в индивидуальном состоянии выделили кристаллическое вещество состава $\mathrm{C}_{15} \mathrm{H}_{20} \mathrm{O}_{4}$ и т.пл.177-179 ${ }^{\circ} \mathrm{C}$ (из водного этанола), которое при хроматографировании на пластинке Silufol UV 254 дало одно пятно Rf 0,40 (растворитель - хлороформ).

На основании данных, полученных при расшифровке ИК-спектров: полосы поглощения ОН-группы $\left(3510 \mathrm{~cm}^{-1}\right), \mathrm{CO}-\gamma$-лактонного цикла $\left(1775 \mathrm{~cm}^{-1}\right)$, сопряженной кетонной группы шестичленного цикла (циклогексанон) $1673 \mathrm{~cm}^{-1}$, и ЯМР-спектров: 0,92 м.д. (синглет, $3 \mathrm{H}, \mathrm{CH}_{3}-\mathrm{C}<$ ), 1,30 м.д. (дуплет, 3Н, $\mathrm{CH}_{3}-\mathrm{C}-$ ) и 1,60 м.д. (синглет, 3H, $\left.\mathrm{CH}_{3}-\mathrm{C}-\mathrm{OH}\right),\left(4,20\right.$ м.д. $\left.\mathrm{J}_{1}=9 ; \mathrm{J}_{2}=11 \mathrm{~Hz}\right),(5,85$ и 6,55 м.д., 1H, J=10 Hz), а также путем непосредственного сравнения спектральных данных (ИК- и ЯМР-спектров) этого соединения с таковыми достоверного образца тауремизина позволило идентифицировать его с последним [12-14].

Исследование антимутагенных свойств тауремизина проводили на семенах мягкой пшеницы (Triticum aestivum L. var. graecum).

Облучение семян в дозе 10 грей производили на установке РХУНД 20000 (мощность 62 рад/с). Было взято два контроля: контроль необлученных семян и контроль с облученными семенами. Оба контроля проращивались в чашках Петри на дистиллированной воде. Другая партия облученных семян проращивалась на растворах тауремизина $0,1,0,01,0,001,0,0001$ мг/мл в термостате при температуре $23-25^{\circ} \mathrm{C}$. Корешки двухдневных проростков длиной 8-11 мм фиксировали в растворе Карнуа (смесь этилового спирта с ледяной уксусной кислотой в соотношении $3: 1$ ). Корешки окрашивались кармином, приготовленным по методу Гренахера $[15,16]$. Учет перестроек хромосом апикальной меристемы корешков проводили по одной из стандартных методик, анафазно-телофазным методом. В каждом варианте опыта просматривали от 800 и более анафазных клеток. Все полученные экспериментальные данные подвергнуты статистической обработке известным математическим методом [17]. 
Влияние тауремизина на облученные гамма-лучами семена пшеницы

\begin{tabular}{|c|c|c|c|c|c|}
\hline \multirow{3}{*}{ Варианты концентрации } & \multirow{3}{*}{$\begin{array}{l}\text { Всего просмот- } \\
\text { ренных анафаз }\end{array}$} & \multicolumn{2}{|c|}{ Анафазы } & \multirow{3}{*}{$t d$} & \multirow{3}{*}{$P$} \\
\hline & & \multicolumn{2}{|c|}{ Частота изменений клеток } & & \\
\hline & & $n$ & $M \pm m$ & & \\
\hline Контроль $\mathrm{H}_{2} \mathrm{O}$ & 979 & 21 & $2,14 \pm 0,46$ & - & - \\
\hline Контроль - облучение 10 гр. & 983 & 90 & $9,11 \pm 0,91$ & - & - \\
\hline $0,1 \mathrm{мг/мл}$ & 957 & 40 & $4,17 \pm 0,66$ & 4,41 & $\leq 0,001$ \\
\hline 0,01 мг/мл & 908 & 28 & $3,08 \pm 0,57$ & 6,71 & $\leq 0,001$ \\
\hline 0,001 мг/мл & 955 & 52 & $5,44 \pm 0,73$ & 3,16 & $\leq 0,005$ \\
\hline 0,0001 мг/мл & 932 & 62 & $6,65 \pm 0,81$ & 2,03 & $\leq 0,005$ \\
\hline
\end{tabular}

\section{Обсуждение результатов}

Результаты влияния сесквитерпенового лактона тауремизина на облученные семена мягкой пшеницы грекум приведены в таблице.

Как видно из таблицы, все примененные концентрации эффективно и достоверно снижают индуцированный уровень аберраций хромосом. Концентрация 0,1 мг/мл снижает уровень аберраций хромосом более чем в 2 раза. Достоверность разницы контрольным и опытными вариантами составляет соответственно 4,17, что превышает 0,1\% уровень значимости по критерию Стьюдента. Максимальный эффект снижения индуцированного $\gamma$-облучением уровня хромосомных аберраций приходится на концентрацию раствора тауремизина 0,01 мг/мл. Эта концентрация снижает уровень индуцированных аберраций хромосом в 3 раза, что почти соответствует контрольному уровню. Отсюда следует, что данная концентрация исследуемого нами вещества способна полностью ликвидировать последствия $\gamma$-облучения. Последующие концентрации также эффективно снижают уровень аберрантных клеток, но с понижением концентрации вещества заметно снижается его антимутагенный эффект. Поэтому в применении более низких концентраций не было необходимости. Достоверность разницы по критерию Стьюдента между контрольным вариантом и концентрациями тауремизина 0,1 и 0,01 мг/мл равен $1 \%$, а достоверность разницы между контролем и концентрациями тауремизина 0,001 и 0,0001мг/мл равна $5 \%$-ному уровню.

Таким образом, результаты проведенного исследования впервые выявили антимутагенную активность вещества тауремизина, выделенного из надземной части Artemisia taurica Willd.

\section{Виводы}

1. Впервые установлена антимутагенная активность сесквитерпенового лактона тауремизина из надземной части (Artemisiataurica Willd.), а также способность подавлять индуцированный мутационный процесс в клетках Triticum aestivum L. var. graecum.

2. Выявлены концентрации тауремизина, которые способны подавлять последствия радиации.

3. Для данного вещества выявлена самая эффективная концентрация (0,01 мг/мл).

\section{Списоклитературы}

1. Алекперов У.К. Антимугагены и проблемы защиты генетического аппарата. Баку, 1989. 112 с.

2. Алекперов У.К. Антимугагенез. М., 1984. 104 с.

3. Алекперов У.К., Мехтизаде Э.Р. Физиология регуляции мутагенеза. Баку, 1989. 144 с.

4. Гроздинский Д.М. Биофизика растений. Киев, 1972. 256 с.

5. Агабейли Р.А. Растительные биокомплексы в предотвращении мутационной изменчивости организмов в процессе старения и воздействия генотоксикантов среды // Biodiversity Protection Proceedings of the Azerbaijan National Man And Biosphere (MAB) Committee. Vol. 2. UNESCO, MAB. Baku. 2003. Pp. 56-71.

6. Ахунд-Заде А.И., Кулиев Р.А., Бахышова Ш.Н. Генозащитное действие маслиновой кислоты при радиационном и химическом мутагенезе // Известия Бакинского университета. Серия естеств. наук. 2006. №2. С. 64-70.

7. Алекперов У.К. Антимугагенез // Проблемы защиты генома. Баку, 2002. С. 3-9.

8. Агабейли Р.А., Кулиев Р.А., Керимова А.И. Сравнительная оценка генетической активности сапонинов из лекарственных растений // Известия Бакинского университета. Серия естеств. наук. 2006. №3. С. 52-57.

9. Сафарова А.Г. Сесквитерпеновые лактоны Artemisia absinthium L., A. taurica Willd. и A. fragrans Willd. и их хемотаксономическое значение : автореф. дис... канд. биол. наук. Баку, 2002. 28 с.

10. Рыбалко К.С. Природные сесквитерпеновые лактоны. М., 1978. 320 с.

11. Лесков А.И., Лакоза Г.Н. К фармакологии тауремизина // Фармакология и токсикология. 1966. №4. С. 444.

12. Кагарлицкий А.Д., Адекенов С.М., Куприянов А.Н. Сесквитерпеновые лактоны растений Центрального Казахстана. Алма-Ата, 1887. 239 с. 
13. Алескерова А.Н., Серкеров С.В. Сесквитерпеновые лактоны нового для Азербайджана вида полыни // Известия АН Азерб. ССР. 1986. №4. С. 28-30.

14. Серкеров С.В. Терпеноиды и фенолпроизводные растений семейств Asteraceae и Apiaceae. Баку, 2005. 311 c.

15. Фрайштат Д.М. Реактивы и препараты для микроскопии. М., 1980, 480 с.

16. Паушева З.П. Практикум по цитологии растений. М., 1988. 271 с.

17. Лакин Т.Ф. Биометрия. М., 1990, 349 с.

Поступило в редакциию 3 июля 2013 2.

После переработки 21 ноября 2013 г.

\author{
Bakhshiyeva N.Ch. ${ }^{1}$, Serkerov S.V. ${ }^{2 *}$ GENE-PROTECTOR FEATURES OF SESQUITERPENE LACTONE TAURE- \\ MISIN \\ ${ }^{I}$ Institute of Genetic Resources of Azerbaijan National Academy of Sciences, Azadlig Ave., 155, Baku, AZ1 106 (Azer- \\ baijan) \\ ${ }^{2}$ Institute of Botany of Azerbaijan National Academy of Sciences, Badamdar highway 40, Baku, AZ1073 (Azerbaijan), e- \\ mail:s.serkerov@mail.ru
}

In article the isolation of sesquiterpene lactone tauremisin from Artemisia taurica with aim to identify its possible antimutagenic effect has been described. Influence of the lactone tauremisin on frequency of chromosome aberrations in the seeds of wheatinducedbyy-irradiationhad been showed. Antimutagenic activity of tauremisin concerning to the mutational process induced by $\gamma$-irradiation in the seeds of wheat (Triticum aestivum L.var.graecum) estimated and its most effective concentration established.

Keywords: Artemisia taurica; sesquiterpene lactones; antimutagenic activity; chromosome aberration; mitotic activity; seed germination.

\title{
References
}

1. Alekperov U.K. Antimutageny i problemy zashchity geneticheskogo apparata. [Antimutagens and security problems of the genetic apparatus]. Baku, 1989, 112 p. (in Russ.).

2. Alekperov U.K. Antimutagenez. [Antimutagenesis]. Moscow, 1984, 104 p. (in Russ.).

3. Alekperov U.K., Mekhtizade E.R. Fiziologiia reguliatsii mutageneza. [Physiology of the regulation of mutagenesis]. Baku, 1989, 144 p. (in Russ.).

4. Grozdinskii D.M. Biofizika rastenii. [Biophysics of plants]. Kiev, 1972, 256 p. (in Russ.).

5. Agabeili R.A. Biodiversity Protection Proceedings of the Azerbaijan National Man And Biosphere (MAB) Committee. Vol. 2. UNESCO, MAB. Baku, 2003, pp. 56-71.

6. Akhund-Zade A.I., Kuliev R.A., Bakhyshova Sh.N. Izvestiia Bakinskogo universiteta. Seriia estestv. nauk, 2006, no. 2, pp. 64-70. (in Russ.).

7. Alekperov U.K. Problemy zashchity genoma. [Problems of protection of the genome]. Baku, 2002, pp. 3-9. (in Russ.).

8. Agabeili R.A., Kuliev R.A., Kerimova A.I. Izvestiia Bakinskogo universiteta. Seriia estestv. nauk., 2006, no. 3, pp. 52-57. (in Russ.).

9. Safarova A.G. Seskviterpenovye laktony Artemisia absinthium L., A. taurica Willd. i A. fragrans Willd. $i$ ikh khemotaksonomicheskoe znachenie: avtoref. dis... kand. biol. nauk. [Sesquiterpene lactones Artemisia absinthium L., A. taurica Willd. and A. fragrans Willd. and their chemotaxonomic value: Dissertation of the candidate biological sciences]. Baku, 2002, 28 p. (in Russ.).

10. Rybalko K.S. Prirodnye seskviterpenovye laktony. [Natural sesquiterpene lactones]. Moscow, 1978, 320 p. (in Russ.).

11. Leskov A.I., Lakoza G.N. Farmakologiia i toksikologiia, 1966, no. 4, p. 444. (in Russ.).

12. Kagarlitskii A.D., Adekenov S.M., Kupriianov A.N. Seskviterpenovye laktony rastenii Tsentral'nogo Kazakhstana. [Sesquiterpene lactones plants in Central Kazakhstan]. Alma-Ata, 1887, 239 p. (in Russ.).

13. Aleskerova A.N., Serkerov S.V. Izvestiia AN Azerb. SSR., 1986, no. 4, pp. 28-30. (in Russ.).

14. Serkerov S.V. Terpenoidy i fenolproizvodnye rastenii semeistv Asteraceae i Apiaceae. [Terpenoids and fenolproizvodnye plants of the Asteraceae and Apiaceae]. Baku, 2005, 311 p. (in Russ.).

15. Fraishtat D.M. Reaktivy i preparaty dlia mikroskopii. [Reagents and preparations for microscopy]. Moscow, 1980, 480 p. (in Russ.).

16. Pausheva Z.P. Praktikum po tsitologii rastenii. [Workshop on Plant Cytology]. Moscow, 1988, 271 p. (in Russ.).

17. Lakin T.F. Biometriia. [Biometriya]. Moscow, 1990, 349 p. (in Russ.).

\footnotetext{
* Corresponding author.
} 